\title{
Association of Red Blood Cell and Platelet Transfusions With Persistent Inflammation, Immunosuppression, and Catabolism Syndrome in Critically III Patients
}

Ginga Suzuki ( $\nabla$ ginga.suzuki@med.toho-u.ac.jp )

Toho University Omori Medical Center

Ryo Ichibayashi

Toho University Omori Medical Center

Yuka Masuyama

Toho University Omori Medical Center

Saki Yamamoto

Toho University Omori Medical Center

Hibiki Serizawa

Toho University Omori Medical Center

Yoshimi Nakamichi

Toho University Omori Medical Center

Masayuki Watanabe

Toho University Omori Medical Center

Mitsuru Honda

Toho University Omori Medical Center

\section{Research Article}

Keywords: persistent inflammation, immunosuppression, and catabolism syndrome (PIICS), red blood cell, platelet, critically ill patients, transfusions

Posted Date: September 8th, 2021

DOl: https://doi.org/10.21203/rs.3.rs-869129/v1

License: (9) (1) This work is licensed under a Creative Commons Attribution 4.0 International License. Read Full License 
Version of Record: A version of this preprint was published at Scientific Reports on January 12th, 2022. See the published version at https://doi.org/10.1038/s41598-021-04327-z. 


\section{Abstract}

The objective of this single-center retrospective cohort study was to investigate the relationship between blood transfusion and persistent inflammation, immunosuppression, and catabolism syndrome (PIICS). The study was conducted at the Critical Care Center at Toho University Omori Medical Center, Japan. We included 391 patients in the PIICS group (hospitalization for $>15$ days, C-reactive protein $>3.0 \mathrm{mg} / \mathrm{dL}$ or albumin $<3.0 \mathrm{mg} / \mathrm{dL}$ or lymph $<800 / \mu \mathrm{L}$ on day 14 ) and 762 patients in the non-PIICS group (hospitalization for $>15$ days and not meeting the PIICS criteria). We performed univariate and multivariate logistic regression analyses using PIICS as the objective variable and red blood cell (RBC) or fresh frozen plasma or platelet (PLT) transfusion and other confounding factors as explanatory variables. In addition, we conducted sensitivity analysis using propensity score matching analysis. The multivariate and propensity score analyses showed that RBC and PLT transfusions were significantly associated with PIICS. This is the first study to report an association between RBC and PLT transfusions and PIICS. Our findings have contributed to better understanding the risk factors of PIICS and suggest that physicians should consider the risk of PIICS occurrence when administering blood transfusions in intensive care unit (ICU) patients.

\section{Introduction}

Persistent inflammation, immunosuppression, and catabolism syndrome (PIICS) has been recently described in critically ill adults and has since been receiving increasing attention. PIICS is mainly characterized by persistent inflammation, which is accompanied by immunosuppression and catabolism [1-3] and often affects patients in the intensive care unit (ICU) and may affect their prognosis. The original diagnostic criteria were length of hospital stay $>14$ days, C-reactive protein (CRP) $>0.15 \mathrm{mg} / \mathrm{dL}$, lymphocyte count $<800 / \mu \mathrm{L}$, weight loss $>10 \%$ or body mass index $<18$ during hospital stay, creatinine height index $<80 \%$, albumin $<3.0 \mathrm{mg} / \mathrm{dL}$, pre-albumin $<10 \mathrm{mg} / \mathrm{dL}$, and retinol-binding protein $<10 \mu \mathrm{g} / \mathrm{dL}$ [1-3]. However, in 2020, Nakamura et al. proposed that CRP $>3.0 \mathrm{mg} / \mathrm{dL}$ was an additional appropriate criterion [4]. Nakamura et al. also identified the presence of disseminated intravascular coagulation (DIC) at admission as a factor associated with PIICS [5].

Nevertheless, further evidence is required to identify the exact risk factors of PIICS. One potential risk factor of PIICS is blood transfusion; however, no study published to date has investigated the relationship between blood transfusion and PIICS. Trauma and surgery patients in the ICU often receive blood transfusions. In addition, anemia progresses in ICU patients without obvious bleeding [6-10]. The causative factors underlying anemia progression in ICU patients are not only acute bleeding but also blood dilution, dysregulation of iron metabolism, and blunting of erythropoietin response by inflammatory cytokines $[8,9]$. Blood products can cause transfusion-related immune modification (TRIM) that suppresses immunity [11-13]. Furthermore, the transfusion of red blood cell (RBC) products and platelets (PLT) are risk factors for nosocomial infections in various environments [14-17]. Moreover, Péju et al. reported that the administration of fresh frozen plasma (FFP) and PLT products in patients with sepsis increases the risk of infections after transfusion [18]. Péju et al. concluded that TRIM may also be present 
in FFP and PLT. Additionally, blood transfusion affects the immune system, especially in ICU patients, where blood transfusion is a frequently performed procedure.

We hypothesized that blood transfusion is associated with the onset of PIICS in ICU patients. Therefore, the aim of this study was to investigate the relationship between blood transfusions and PIICS.

\section{Methods}

\section{Design, Setting, and Ethics approval}

This is a single-center, retrospective cohort study, planned and conducted at the Critical Care Center, Toho University Omori Medical Center, in accordance with the Declaration of Helsinki as revised in 2013. It was approved by the Ethics Committee of the Toho University Omori Medical Center (approval number M20260). Due to the retrospective nature of the study, the need for written informed consent was waived.

\section{Subjects}

The subjects were tertiary emergency patients admitted to the ICU between January 2019 and March 2021. Patients with acute deterioration in the hospital or those scheduled to undergo surgery were not included. The exclusion criteria were age $<18$ years and death within 14 days of admission to the ICU.

\section{Data collection}

At this hospital, the profile, physical examination findings, laboratory findings, and treatment details of patients are recorded electronically. These electronic medical records were used as the data resource, and data retrieval began in July 2021. The following information was extracted from the medical records: patient profile (age, sex, height, and weight); presence of sepsis (yes or no); surgical history; comorbidity (Charlson Comorbidity Index [CCI] score [19]); acute physiology and chronic health evaluation (APACHE) II score; DIC (International Society on Thrombosis and Hemostasis [ISTH]-overt DIC) [20] at admission; the presence of renal replacement therapy (RRT); received extracorporeal membrane oxygenation (ECMO; yes or no); received blood transfusion (RBC, or FFP, or PLT; yes or no); were administered steroids (yes or no). The following data from blood test results were extracted: CRP and albumin levels, lymphocyte count on admission and on day 14 , creatinine $(\mathrm{Cr})$ and hemoglobin $(\mathrm{Hb})$ levels, PLT count, prothrombin time, fibrinogen, fibrin or fibrinogen degradation products (FDP), and lactate and glycated hemoglobin (HbA1c) levels. If there were no data available on day 14 , the nearest values within days $12-16$ were used instead.

\section{Definition of PIICS}

Patients who required hospitalization for $>15$ days and met the criteria of CRP $>3.0 \mathrm{mg} / \mathrm{dL}$ or albumin $<$ $3.0 \mathrm{mg} / \mathrm{dL}$ or lymph $<800 / \mu \mathrm{L}$ on day 14 were assigned to the PIICS group [4,5]. Patients who required hospitalization for $>15$ days and did not meet the PIICS criteria were assigned to the non-PIICS group.

\section{Outcome}


The primary outcome was PIICS onset and the secondary outcome was 90-day mortality.

\section{Statistical analysis}

We used the Kolmogorov-Smirnov test to test the normality assumption of our data; the variable was treated as following an abnormal distribution when the null hypothesis was rejected at $5 \%$ and as following a normal distribution when the null hypothesis was accepted. If the continuous variable had an abnormal distribution, it was expressed as the median (interquartile range) and tested using MannWhitney's $U$ test; if it was a normal distribution, it was expressed as mean \pm standard deviation and tested using Student's t-test. Categorical variables were expressed as percentages and tested using the chisquare test.

To analyze the factors related to the onset of PIICS, univariate analysis was performed with PIICS as the objective variable and with each of the following factors as explanatory variables: patient profile (age, sex, height, and weight); factors involved in the diagnosis of PIICS (CRP and albumin levels and lymphocyte count); factors reported as potential risk factors in previous studies (sepsis; $\mathrm{Cr}, \mathrm{Hb}$, and HbA1c levels, overt DIC, and APACHE II score) [5]; history of steroid use; and blood transfusion (RBC, FFP, PLT). Next, a multivariate logistic regression analysis was performed with PIICS as the objective variable and all the above variables as explanatory variables. Variance inflation factor was calculated for each factor, and if it was $<10$, the factors were confirmed to have no multicollinearity. In addition, a receiver operating characteristic (ROC) curve was drawn to evaluate the diagnostic value of the volume of RBC transfused in predicting PIICS in ICU patients and the area under the curve (AUC) was calculated.

Next, sensitivity analysis using propensity score matching was performed. Propensity scores were calculated using a logistic regression model with the presence or absence of RBC transfusion as the objective variable and the following factors as explanatory variables that may have been considered in performing RBC transfusion: age; sex; height; weight; presence of sepsis; underwent surgery; $\mathrm{CCl}$; $\mathrm{Hb}$ level; PLT counts; prothrombin time; fibrinogen, FDP, and lactate concentrations; APACHE II score; overt DIC; RRT; and ECMO. After calculating the propensity score, a caliper width of 0.2 was used for nearest neighbor matching. Multivariate logistic regression analysis was performed with a matched cohort using PIICS as the objective variable and the following factors as the explanatory variables: CRP, albumin, and Cr levels; lymphocyte counts, HbA1c levels; received steroids or blood transfusion (RBC, FFP, PLT). The explanatory factors used in the multivariate analysis were selected as a result of excluding the factors used to calculate the propensity score. Statistical analyses were performed using StatFlex ${ }^{\circledR}$ version 7 (Artech Co., Ltd., Osaka, Japan). Statistical significance was set at $\mathrm{P}<0.05$.

\section{Results}

During the observation period, 1,426 patients were admitted to the ICU from the tertiary emergency department. Forty-two patients were excluded because they were $<18$ years old. Out of the remaining 1,384 patients, 231 patients died within 14 days and were also excluded. As a result, 762 patients were grouped into the non-PIICS group and 391 patients into the PIICS group (Fig. 1). 
Significant differences in most of the baseline factors were observed between the two groups (Table 1). 
Table 1

Basic characteristics of overall and matched cohort.

\section{Overall cohort}

Matched cohort

\begin{tabular}{|c|c|c|c|c|c|c|}
\hline & Overall cohort & & & Matched coh & & \\
\hline Variable & $\begin{array}{l}\text { Non-PIICS } \\
\text { group }(\mathrm{N}=762)\end{array}$ & $\begin{array}{l}\text { PIICS group } \\
(\mathrm{N}=391)\end{array}$ & $\mathrm{p}$ & $\begin{array}{l}\text { Non-PIICS } \\
\text { group }(\mathrm{N}= \\
144)\end{array}$ & $\begin{array}{l}\text { PIICS group } \\
(N=162)\end{array}$ & $\mathrm{p}$ \\
\hline Age, years & $62.0(30.0)$ & $72.0(22.0)$ & $\dot{0} 01$ & $72.0(23.6)$ & $73.0(20.0)$ & 0.11 \\
\hline Male, n (\%) & $494(65.2 \%)$ & $260(66.5 \%)$ & 0.65 & 94 (65.3\%) & 97 (59.9\%) & 0.33 \\
\hline Height, cm & $162.0(14.0)$ & $160.0(16.0)$ & 0.06 & $160.5(15.9)$ & $160.0(14.0)$ & 0.10 \\
\hline Weight, kg & $57.7(16.0)$ & $55.0(18.7)$ & $\begin{array}{l}<.01 \\
0.01\end{array}$ & $54.5(18.0)$ & $55.1(16.9)$ & 0.61 \\
\hline Sepsis, n (\%) & $24(3.1 \%)$ & 57 (14.6\%) & $\dot{<} 01$ & $10(6.9 \%)$ & 31 (19.1\%) & $\begin{array}{l}< \\
0.01\end{array}$ \\
\hline $\begin{array}{l}\text { Surgical } \\
\text { procedure, n (\%) }\end{array}$ & $45(5.9 \%)$ & $110(28.1 \%)$ & $\begin{array}{l}< \\
0.01\end{array}$ & $29(20.1 \%)$ & $54(33.3 \%)$ & 0.01 \\
\hline $\begin{array}{l}\text { Charlson } \\
\text { comorbidity } \\
\text { index }\end{array}$ & $0(2.0)$ & $1.0(2.0)$ & $\begin{array}{l}< \\
0.01\end{array}$ & $1.0(1.0)$ & $1.0(1.0)$ & 0.55 \\
\hline \multicolumn{7}{|l|}{$\begin{array}{l}\text { Blood test on } \\
\text { admission }\end{array}$} \\
\hline $\begin{array}{l}\text { C-reactive } \\
\text { protein, } \mathrm{mg} / \mathrm{dL}\end{array}$ & $0.1(0.6)$ & $0.8(5.8)$ & $\dot{<} 01$ & $0.2(1.4)$ & $0.9(6.0)$ & $\begin{array}{l}< \\
0.01\end{array}$ \\
\hline Albumin, $\mathrm{mg} / \mathrm{dL}$ & $3.9(0.9)$ & $3.3(1.1)$ & $\begin{array}{l}<.01 \\
0.01\end{array}$ & $3.6(0.9)$ & $3.3(1.3)$ & 0.03 \\
\hline $\begin{array}{l}\text { Creatinine, } \\
\mathrm{mg} / \mathrm{mL}\end{array}$ & $0.9(0.5)$ & $1.1(1.0)$ & $\dot{0} 01$ & $1.0(0.9)$ & $1.2(1.0)$ & 0.20 \\
\hline $\begin{array}{l}\text { Lymphocyte } \\
\text { counts, } / \mu \mathrm{L}\end{array}$ & $\begin{array}{l}1849.0 \\
(1876.8)\end{array}$ & $\begin{array}{l}1185.0 \\
(1986.9)\end{array}$ & <. 01 & $\begin{array}{l}1439.5 \\
(1945.2)\end{array}$ & $\begin{array}{l}1139.5 \\
(2136.9)\end{array}$ & 0.40 \\
\hline $\begin{array}{l}\text { Hemoglobin, } \\
\text { g/dL }\end{array}$ & $13.4(3.1)$ & $12.7(4.1)$ & $\begin{array}{l}<.01 \\
0.01\end{array}$ & $11.3(4.0)$ & $12.3(4.0)$ & 0.02 \\
\hline $\begin{array}{l}\text { Platelet counts, } \\
\times 10^{4} / \mu \mathrm{L}\end{array}$ & $23.3(9.5)$ & $20.7(11.6)$ & $\dot{0} 01$ & $21.3(11.4)$ & $20.9(12.7)$ & 0.58 \\
\hline $\begin{array}{l}\text { Prothrombin } \\
\text { time, sec }\end{array}$ & $11.7(2.4)$ & $12.4(3.1)$ & $\begin{array}{l}<.01 \\
0.01\end{array}$ & $12.1(2.3)$ & $12.4(3.0)$ & 0.09 \\
\hline
\end{tabular}

FDP: fibrin/fibrinogen degradation products; APACHE: acute physiologic and chronic health evaluation; DIC: disseminated intravascular coagulation; RRT: renal replacement therapy; ECMO: extracorporeal membrane oxygenation; PIICS: persistent inflammation, immunosuppression, and catabolism syndrome 


\begin{tabular}{|c|c|c|c|c|c|c|}
\hline & \multicolumn{3}{|l|}{ Overall cohort } & \multicolumn{3}{|l|}{ Matched cohort } \\
\hline $\begin{array}{l}\text { Fibrinogen, } \\
\mathrm{mg} / \mathrm{dL}\end{array}$ & $272.0(103.0)$ & $\begin{array}{l}311.0 \\
(171.8)\end{array}$ & $\begin{array}{l}< \\
0.01\end{array}$ & $278.5(130.5)$ & $\begin{array}{l}307.0 \\
(162.0)\end{array}$ & 0.02 \\
\hline $\mathrm{FDP}, \mu \mathrm{g} / \mathrm{mL}$ & $4.8(9.6)$ & $13.1(32.7)$ & $\begin{array}{l}< \\
0.01\end{array}$ & $8.3(24.2)$ & $11.8(37.1)$ & 0.01 \\
\hline $\begin{array}{l}\text { Lactate, } \\
\mathrm{mmol} / \mathrm{L}\end{array}$ & $2.7(3.2)$ & $3.4(5.3)$ & $\begin{array}{l}< \\
0.01\end{array}$ & $2.7(3.5)$ & $3.1(5.1)$ & 0.20 \\
\hline $\mathrm{HbA} 1 \mathrm{c}, \%$ & $5.6(0.7)$ & $5.7(1.0)$ & 0.01 & $5.6(0.7)$ & $5.7(1.0)$ & $<.01$ \\
\hline APACHE II score & $14.0(12.0)$ & $20.0(12.0)$ & $\hat{0}_{0.01}$ & $17.0(11.0)$ & $20.0(11.0)$ & 0.01 \\
\hline Overt DIC, (\%) & $9(1.2 \%)$ & $21(5.4 \%)$ & $\begin{array}{l}< \\
0.01\end{array}$ & $6(4.2 \%)$ & $9(5.6 \%)$ & 0.57 \\
\hline RRT, (\%) & 33 (4.4\%) & 39 (10.0\%) & $\begin{array}{l}< \\
0.01\end{array}$ & 12 (8.3\%) & $18(11.1 \%)$ & 0.41 \\
\hline ECMO, (\%) & $3(0.4 \%)$ & $24(6.1 \%)$ & $\begin{array}{l}< \\
0.01\end{array}$ & $0(0 \%)$ & $0(0 \%)$ & $\mathrm{N} / \mathrm{A}$ \\
\hline \multicolumn{7}{|c|}{$\begin{array}{l}\text { FDP: fibrin/fibrinogen degradation products; APACHE: acute physiologic and chronic health } \\
\text { evaluation; DIC: disseminated intravascular coagulation; RRT: renal replacement therapy; ECMO: } \\
\text { extracorporeal membrane oxygenation; PIICS: persistent inflammation, immunosuppression, and } \\
\text { catabolism syndrome }\end{array}$} \\
\hline
\end{tabular}

There were also significant differences in all risk factors between the two groups for each factor on day 14 and when subsequently assessing the 90-day mortality rate (Table 2 ). 
Table 2

Variables on day 14 and outcomes.

\begin{tabular}{|c|c|c|c|c|c|c|}
\hline & Overall cohort & & & Matched cohort & & \\
\hline Variable & $\begin{array}{l}\text { Non-PIICS } \\
\text { group }(\mathrm{N}= \\
762)\end{array}$ & $\begin{array}{l}\text { PIICS group } \\
(\mathrm{N}=391)\end{array}$ & $\mathrm{p}$ & $\begin{array}{l}\text { Non-PIICS } \\
\text { group }(\mathrm{N}= \\
144)\end{array}$ & $\begin{array}{l}\text { PIICS group } \\
(N=162)\end{array}$ & $\mathrm{p}$ \\
\hline \multicolumn{7}{|l|}{$\begin{array}{l}\text { Blood test on } \\
\text { day } 14\end{array}$} \\
\hline $\begin{array}{l}\text { C-reactive } \\
\text { protein, } \mathrm{mg} / \mathrm{dL}\end{array}$ & $0.5(1.5)$ & $3.6(5.8)$ & $\dot{0} 01$ & $0.8(1.8)$ & $3.4(4.8)$ & $\begin{array}{l}< \\
0.01\end{array}$ \\
\hline Albumin, mg/dL & $3.5(0.7)$ & $2.4(0.7)$ & $\begin{array}{l}< \\
0.01\end{array}$ & $3.2(0.7)$ & $2.4(0.6)$ & $\begin{array}{l}< \\
0.01\end{array}$ \\
\hline $\begin{array}{l}\text { Lymphocyte } \\
\text { counts, / } \mu \mathrm{L}\end{array}$ & $1432.9(869.5)$ & $\begin{array}{l}1008.0 \\
(688.2)\end{array}$ & $\begin{array}{l}< \\
0.01\end{array}$ & 1259.5 (754.2) & $\begin{array}{l}979.9 \\
(621.0)\end{array}$ & $<0.01$ \\
\hline \multicolumn{7}{|l|}{$\begin{array}{l}\text { Blood products } \\
\text { on day } 14\end{array}$} \\
\hline $\begin{array}{l}\text { Red blood cell, } n \\
(\%)\end{array}$ & $83(10.9 \%)$ & 193 (49.4\%) & $\dot{0} 01$ & 48 (33.3\%) & 105 (64.8\%) & $<.01$ \\
\hline Plasma, ml, n (\%) & $38(5.0 \%)$ & $110(28.1 \%)$ & $\begin{array}{l}< \\
0.01\end{array}$ & $17(11.8 \%)$ & $43(26.5 \%)$ & $\begin{array}{l}< \\
0.01\end{array}$ \\
\hline Platelet, n (\%) & $6(0.8 \%)$ & $69(17.6 \%)$ & $\begin{array}{l}< \\
0.01\end{array}$ & $2(1.4 \%)$ & $24(14.8 \%)$ & $<$. \\
\hline $\begin{array}{l}\text { Steroids use on } \\
\text { day } 14, \mathrm{n}(\%)\end{array}$ & $36(4.8 \%)$ & $54(13.9 \%)$ & $\begin{array}{l}< \\
0.01\end{array}$ & $12(8.3 \%)$ & $16(9.9 \%)$ & 0.63 \\
\hline 90-day mortality & $2(0.3 \%)$ & $57(14.6 \%)$ & $\begin{array}{l}<.01 \\
0.01\end{array}$ & $0(0 \%)$ & $21(13.0 \%)$ & $<.01$ \\
\hline
\end{tabular}

In the univariate analysis of the overall cohort, all factors except sex were significantly associated with PIICS. In addition, the multivariate analysis showed that sepsis, surgery, albumin level, lymphocyte count, $\mathrm{Hb}$ level, APACHE II score, RBC count, and PLT transfusion were significantly associated with PIICS (Table $3)$. 
Table 3

Univariate and multivariate analysis of PIICS in the overall cohort.

\section{Univariate analysis}

\begin{tabular}{|c|c|c|c|c|c|}
\hline Parameters & Odds ratio $(95 \% \mathrm{Cl})$ & $\begin{array}{l}P \\
\text { value }\end{array}$ & Odds ratio $(95 \% \mathrm{Cl})$ & $P$ value & VIF \\
\hline Age & $1.032(1.025-1.040)$ & $<0.01$ & $1.011(0.998-1.023)$ & 0.10 & 1.95 \\
\hline Male & $1.061(0.820-1.372)$ & 0.65 & $0.956(0.592-1.541)$ & 0.85 & 2.00 \\
\hline Height & $0.987(0.974-1.000)$ & 0.04 & $0.991(0.964-1.020)$ & 0.54 & 2.70 \\
\hline Weight & $0.988(0.979-0.997)$ & 0.01 & $1.007(0.992-1.022)$ & 0.39 & 1.74 \\
\hline Sepsis & $5.248(3.202-8.601)$ & $<0.01$ & $2.305(1.222-4.347)$ & 0.01 & 1.37 \\
\hline Surgical procedure & $6.202(4.270-9.009)$ & $<0.01$ & $\begin{array}{l}7.545(4.420- \\
12.879)\end{array}$ & $<0.01$ & 1.40 \\
\hline $\mathrm{CCl}$ & $1.120(1.028-1.220)$ & 0.01 & $0.992(0.878-1.122)$ & 0.90 & 1.33 \\
\hline C-reactive protein & $1.086(1.062-1.109)$ & $<0.01$ & $1.026(0.997-1.054)$ & 0.08 & 1.68 \\
\hline Albumin & $0.367(0.306-0.441)$ & $<0.01$ & $0.474(0.346-0.651)$ & $<0.01$ & 2.38 \\
\hline Creatinine & $1.108(1.036-1.186)$ & $<0.01$ & $0.919(0.822-1.027)$ & 0.14 & 1.54 \\
\hline $\begin{array}{l}\text { Lymphocyte } \\
\text { counts }\end{array}$ & $1.000(1.000-1.000)$ & $<0.01$ & $1.000(1.000-1.000)$ & 0.02 & 1.21 \\
\hline $\mathrm{HbA} 1 \mathrm{c}$ & $1.125(1.028-1.230)$ & 0.01 & $1.070(0.956-1.199)$ & 0.24 & 1.13 \\
\hline Hemoglobin & $0.902(0.862-0.943)$ & $<0.01$ & $1.157(1.065-1.258)$ & $<0.01$ & 2.23 \\
\hline APACHE II score & $1.086(1.069-1.104)$ & $<0.01$ & $1.103(1.075-1.131)$ & $<0.01$ & 1.67 \\
\hline Overt DIC & $4.749(2.154-10.471)$ & $<0.01$ & $2.157(0.827-5.623)$ & 0.12 & 1.08 \\
\hline Steroids & $3.228(2.077-5.019)$ & $<0.01$ & $1.496(0.806-2.778)$ & 0.20 & 1.21 \\
\hline Red blood cell & $7.974(5.895-10.786)$ & $<0.01$ & $4.632(2.835-7.568)$ & $<0.01$ & 2.16 \\
\hline Plasma & $7.458(5.031-11.057)$ & $<0.01$ & $0.799(0.406-1.572)$ & 0.52 & 2.35 \\
\hline Platelets & $\begin{array}{l}27.000(11.606- \\
62.815)\end{array}$ & $<0.01$ & $\begin{array}{l}4.828(1.707- \\
13.655)\end{array}$ & $<0.01$ & 1.82 \\
\hline RRT & $2.434(1.505-3.937)$ & $<0.01$ & $1.258(0.574-2.756)$ & 0.57 & 1.41 \\
\hline ECMO & $16.458(4.924-55.009)$ & $<0.01$ & $1.273(0.305-5.310)$ & 0.74 & 1.35 \\
\hline
\end{tabular}


The ROC curve of PIICS for the RBC dose is shown in Fig. 2. The AUC was 0.70.

In the matched cohort, there were 144 patients in the non-PIICS group and 162 in the PIICS group. Compared with the patients in the non-PIICS group, those in the PIICS group had a significantly higher incidence of sepsis and surgery, higher CRP and $\mathrm{Hb}$ levels, fibrinogen, FDP, HbA1c level, APACHE II scores, and lower albumin levels (Table 1 ).

The CRP and albumin levels, lymphocyte counts, blood transfusion (RBC/FFP/PLT) on day 14, and the 90-day mortality rate were significantly higher in the PIICS group than those in the non-PIICS group. (Table 2).

In the multivariate analysis with matched cohorts, CRP and HbA1c levels, and RBC and PLT transfusions were significantly associated with PIICS (Table 4).

Table 4

Multivariate analysis of PIICS in the matched cohort.

\begin{tabular}{|llll|}
\hline \multicolumn{4}{|c|}{ Multivariate analysis } \\
\hline Parameters & Odds ratio $(95 \%$ Cl) & P value & VIF \\
\hline C-reactive protein & $1.042(1.005-1.081)$ & 0.03 & 1.56 \\
\hline Albumin & $0.796(0.532-1.190)$ & 0.27 & 1.37 \\
\hline Creatinine & $0.942(0.824-1.077)$ & 0.38 & 1.15 \\
\hline Lymphocyte counts & $1.000(1.000-1.000)$ & 0.34 & 1.16 \\
\hline HbA1c & $1.381(1.059-1.802)$ & 0.02 & 1.07 \\
\hline Steroids & $0.597(0.223-1.594)$ & 0.30 & 1.18 \\
\hline Red blood cell & $3.084(1.793-5.304)$ & $<0.01$ & 1.26 \\
\hline Plasma & $0.952(0.430-2.107)$ & 0.90 & 1.62 \\
\hline Platelets & $6.344(1.286-31.281)$ & 0.02 & 1.43 \\
\hline $\begin{array}{l}\text { PIICS: persistent inflammation, immunosuppression, and catabolism syndrome; VIF: Variance } \\
\text { inflation factor }\end{array}$ & & \\
\hline
\end{tabular}

\section{Discussion}

The present study results showed that PIICS is significantly associated with RBC and PLT transfusions. This result was consistent even after adjusting by propensity score matching. In addition to RBC and PLT transfusion, PIICS was associated with sepsis, surgery, CRP and albumin levels, lymphocyte count, $\mathrm{Hb}$ and $\mathrm{HbA} 1 \mathrm{c}$ levels, and APACHE II score. 
Nakamura et al. reported that age, sex, sepsis, albumin level, lymphocyte count, $\mathrm{Hb}$ and $\mathrm{HbA} 1 \mathrm{c}$ levels, $\mathrm{Cr}$ level, and overt DIC were significantly associated with PIICS [5]. Thus, the results of the present study are consistent with their findings. However, in contrast to the report by Nakamura et al. [5], which summarized the risk factors for patients admitted to emergency ward and ICU regardless of in-hospital or outpatient settings, the present study included patients admitted to the ICU from the tertiary emergency department. The difference in patient cohorts between the two studies may explain the differences in findings. Specifically, the patients in this study were younger and mostly male. Furthermore, the number of patients with sepsis was smaller and most had a higher APACHE II score than those in the study reported by Nakamura et al [5]. In addition, the overt DIC was surprisingly small in this study. Furthermore, a new analysis was conducted regarding blood transfusion, which may have caused the difference in the results.

The onset of PIICS associated with RBC transfusion is primarily because TRIM reduces immunity [1113]. Second, suppressed immunity leads to increased risk of infection and inflammation after transfusion. Additionally, the association of PLT transfusions with PIICS has been associated with an increased risk of post-transfusion infections [14-17]. However, as reported by Péju et al., it has been suggested that FFP and PLT products may also have an immunosuppressive effect [18], and as identified in this study, PLT administration suppresses immunity, which may have affected the onset of PIICS as there was no association between FFP transfusion and PIICS. However, in FFP, aside from RBC and PLT, there were procedures done in patients with liver failure, such as plasma exchange and infusion, that may have affected our results.

Furthermore, RBC and PLT transfusions were associated with PIICS, suggesting that it would be important to consider transfusion criteria according to various diseases and stages in future studies.

This study has several limitations. First, the characteristics of the patient population may have influenced the results as this was a single-institution retrospective study; thus, the results cannot be generalized. Nevertheless, a relatively large number of samples were collected and analyzed. Second, the effects of confounding factors that were not considered in this study were not removed. Third, patient factors that required RBC transfusion may have influenced the outcome, and the effects were incompletely removed. However, as a countermeasure, propensity score matching analysis was performed. Fourth, there may be cases where the diagnosis of PIICS was inaccurate as there were no data available for day 14 ; in such cases, we included data from the nearest date.

In conclusion, this is the first study to report an association between RBC and PLT transfusions and PIICS. Our findings have contributed to better understanding the risk factors of PIICS and suggest that physicians should consider the risk of occurrence of PIICS when administering blood transfusions in ICU patients.

\section{Declarations}


Not applicable.

\section{Author contributions statement:}

G.S. performed the statistical analyses and drafted the manuscript. G.S., R.I., Y.M., S.Y., H.S., Y.N., M.W., and M.H. contributed to data acquisition. R.I. participated in study design and coordination. M.H. conceived the study, participated in study design and coordination, and contributed to manuscript writing. All authors read and approved the final manuscript.

\section{Competing interests:}

The authors declare no competing interests.

\section{Data availability:}

The datasets used and/or analyzed during the current study are available from the corresponding author upon reasonable request.

\section{Funding:}

None

\section{References}

1. Gentile, L.F., et al. Persistent inflammation and immunosuppression: a common syndrome and new horizon for surgical intensive care. J. Trauma Acute Care Surg. 72, 1491-1501 (2012).

2. Mira, J.C., et al. Sepsis pathophysiology, chronic critical illness, and persistent inflammationimmunosuppression and catabolism syndrome. Crit. Care Med. 45, 253-262 (2017).

3. Mira, J.C., Brakenridge, S.C., Moldawer, L.L., \& Moore, F.A. Persistent inflammation, immunosuppression and catabolism syndrome. Crit. Care Clin. 33, 245-258 (2017).

4. Nakamura, K., et al. C-reactive protein clustering to clarify persistent inflammation, immunosuppression and catabolism syndrome. Intensive Care Med. 46, 437-443 (2020).

5. Nakamura, K., et al. Disseminated intravascular coagulopathy is associated with the outcome of persistent inflammation, immunosuppression and catabolism syndrome. J. Clin. Med. 9, 2662 (2020).

6. Napolitano, L.M. Anemia and red blood cell transfusion: advances in Critical Care. Crit. Care Clin. 33, 345-364 (2017).

7. Cable, C.A., Razavi, S.A., Roback, J.D., \& Murphy, D.J. RBC transfusion strategies in the ICU: a concise review. Crit. Care Med. 47, 1637-1644 (2019).

8. Napolitano, L.M. Understanding anemia in the ICU to develop future treatment strategies. Am. J. Respir. Crit. Care Med. 198, 554-555 (2018). 
9. Hayden, S.J., Albert, T.J., Watkins, T.R., \& Swenson, E.R. Anemia in critical illness: insights into etiology, consequences, and management. Am. J. Respir. Crit. Care Med. 185, 1049-1057 (2012).

10. Prakash D. Anemia in the ICU: anemia of chronic disease versus anemia of acute illness. Crit. Care Clin. 28, 333-343 (2012).

11. Remy, K.E., et al. Mechanisms of red blood cell transfusion-related immunomodulation. Transfusion. 58, 804-815 (2018).

12. Frazier, S.K., Higgins, J., Bugajski, A., Jones, A.R., \& Brown, M.R. Adverse reactions to transfusion of blood products and best practices for prevention. Crit. Care Nurs. Clin. North Am. 29, 271-290 (2017).

13. Vamvakas, E.C., \& Blajchman, M.A. Transfusion-related immunomodulation (TRIM): an update. Blood Rev. 21, 327-348 (2007).

14. Shorr, A.F., Jackson, W.L., Kelly, K.M., Fu, M., \& Kollef, M.H. Transfusion practice and blood stream infections in critically ill patients. Chest. 127, 1722-1728 (2005).

15. Rohde, J.M., et al. Health care-associated infection after red blood cell transfusion: a systematic review and meta-analysis. JAMA. 311, 1317-1326 (2014).

16. Dupuis, C., et al. Effect of transfusion on mortality and other adverse events among critically ill septic patients: an observational study using a Marginal Structural Cox Model. Crit. Care Med. 45, 19721980 (2017).

17. Dupuis, C., et al. Impact of transfusion on patients with sepsis admitted in intensive care unit: a systematic review and meta-analysis. Ann. Intensive Care. 7, 5 (2017).

18. Péju, E., et al. Impact of blood product transfusions on the risk of ICU-acquired infections in septic shock. Crit. Care Med. 49, 912-922 (2021).

19. Charlson, M.E., Pompei, P., Ales, K.L., \& MacKenzie, C.R. A new method of classifying prognostic comorbidity in longitudinal studies: development and validation. J. Chronic Dis. 40, 373-383 (1987).

20. Taylor Jr, F.B., Toh, C.H., Hoots, W.K., Wada, H., Levi, M., \& Scientific Subcommittee on Disseminated Intravascular Coagulation (DIC) of the International Society on Thrombosis and Haemostasis (ISTH). Scientific Subcommittee on Disseminated Intravascular Coagulation (DIC) of the International Society on Thrombosis and Hemostasis (ISTH). Towards definition, clinical and laboratory criteria, and a scoring system for disseminated intravascular coagulation. Thromb. Haemost. 86, 1327-1330 (2001).

\section{Figures}




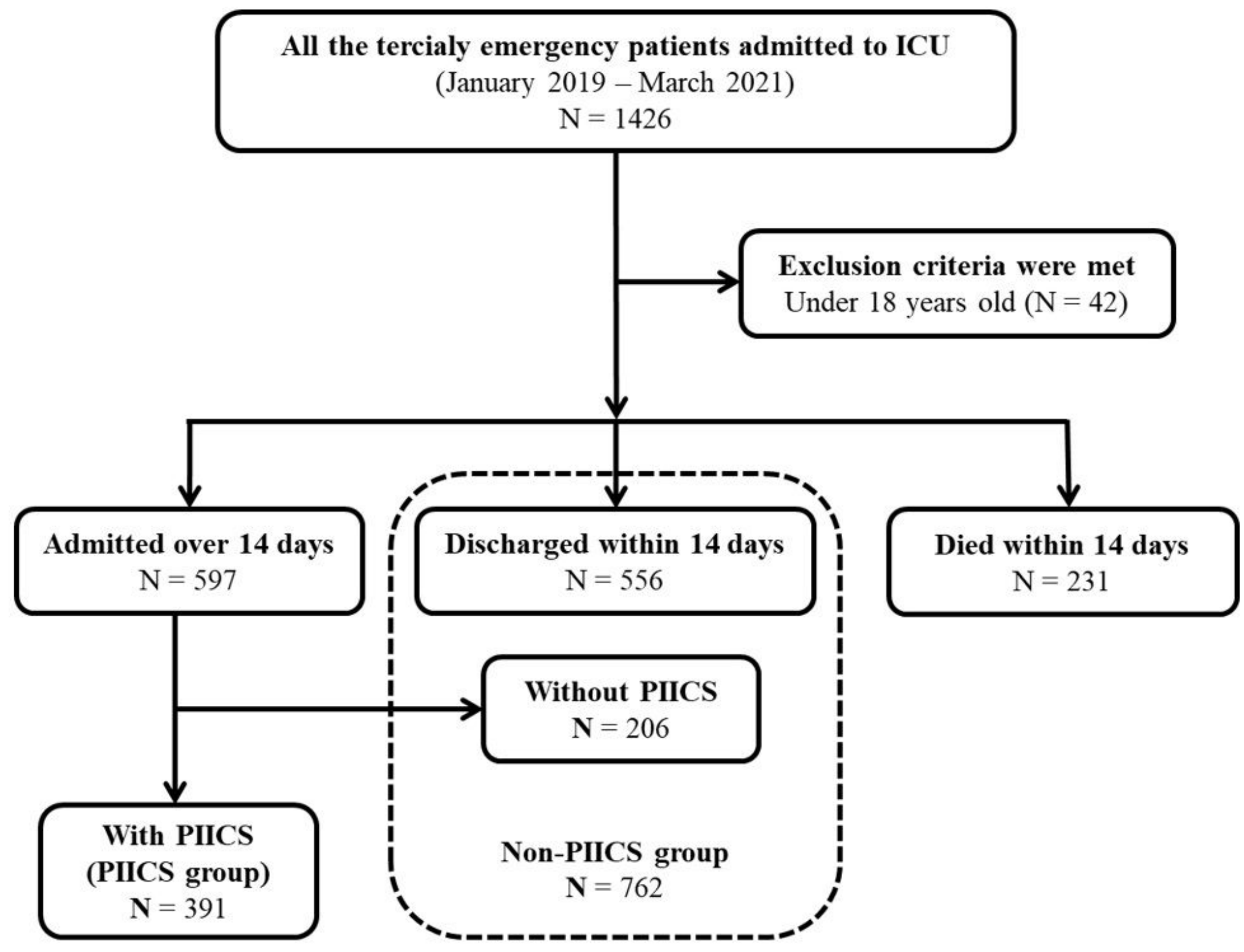

Figure 1

Chart showing the patient selection process. PIICS: persistent inflammation, immunosuppression, and catabolism syndrome 


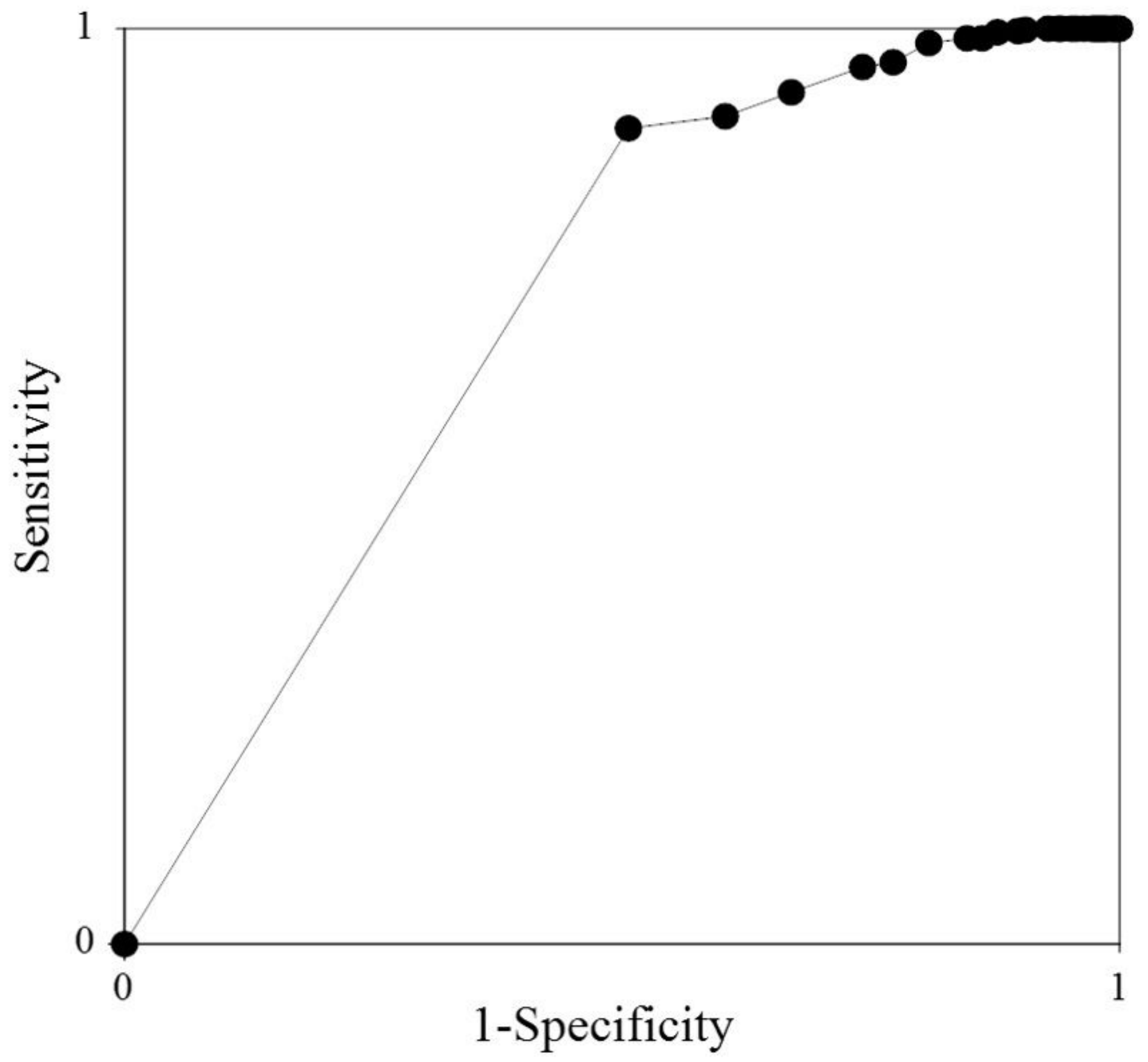

Figure 2

Receiver operating characteristic curve showing the diagnostic value of the volume of red blood cell transfused in predicting PIICS in ICU patients. The area under the curve is 0.70 . ROC: receiver operating characteristic; PIICS: persistent inflammation, immunosuppression, and catabolism syndrome 